\title{
The Role of Integrated Change Control in Project Success within the Telecommunication Industry in Uganda: A case of Airtel Networks LTD, Uganda
}

\author{
Dr. Kirima Lucy Karimi (Corresponding author) \\ School of Business and Economics, University of Embu, Kenya \\ E-mail: mukathakinyua60@gmail.com
}

Antony Munyori

Department of Business Administration, Africa Nazarene University, Kenya

Received: December 6, 2018

Accepted: December 27, 2018 Published: March 14, 2019

doi:10.5296/ber.v9i2.14497

URL: https://doi.org/10.5296/ber.v9i2.14497

\begin{abstract}
The purpose of this research study was to investigate the role of integrated change control in project success within the telecommunication industry in Uganda. Integrated change control allows for documentation of all the requested, approved or rejected changes to the project with an aim of reducing project risks, cost and time without having to consider the overall project objective plans. The target population for this study was the technical staff within IT department, change management team involved in implementing and configuring changes and the management team involved in approving or rejecting changes in Airtel Networks LTD Uganda. The study concluded that, change readiness, communication change plans, change management execution, trainings and change documentation availability and feedback elicitation from all relevant stakeholders play a bigger role in the level of project change success. It was noted further that it is necessary to have a unified change management process that incorporates an integrated change control section comprised of Change board that sits down to review, analyze, approve, reject or return change requests raised by different stakeholders of the organization at any point in time. The study recommended that Airtel Networks LTD Uganda continuously engages in the Change management process with emphasis on integrated change control to exploit fully its internal resources in the strategy implementation process while remaining relevant not only to its own operations but also to the ever-changing environmental dynamics in the telecommunication industry.
\end{abstract}


Keywords: Integrated change control, Change management, Project success, Change board, Change agnet

\section{Introduction}

Project Management Institute (2013), a guide to the Project Management body of Knowledge, defines Integrated change control as the process of reviewing all change requests, approving or rejecting them as a continuous process from project inception through completion. Integrated change control reviews all the requests for changes and modification to the project documents, baselines, deliverables or the project management plan and either approves or rejects the requested changes. Most projects within telecommunication industry get executed in an adhoc way without any documentation, guidelines or procedure. This section describes briefly Information Technology projects undertaken by most telecommunication companies, Airtel Networks LTD, Uganda progress in terms of these projects and finally states the statement of the problem under investigation.

\subsection{Information Technology Projects within the Telecommunication Industry-Remove italics}

Telecommunication industry encompasses all the companies that involve the exchange of information by electronic means through data, voice and video transmission by wireless operators, fiber cable companies, satellite companies and internet service providers with internet being the largest form of telecommunication network.

Teleconferencing and online meetings tools have found popularity in most organizations for purpose of sales demonstration and virtual offices for employees located in different geographical areas which lead to cost effective and convenient. Mobile commerce which involves mobile money transactions, mobile banking and mobile payments are a major revolution in today's telecommunication sector which has been available by all telecom companies at competitive rates (Wieland, 2017).

Other Information technology projects within the telecom industry that undergo changes often include multimedia content services used to deliver specific content to mobile operator customers using short messages services (SMS), multimedia messages services (MMS), device management which include all services used to configure new capabilities or to install new application on user mobile phone, value added services (VAS) which includes all other services offered mainly using third party content providers and the transition of the wireless industry from second generation $(2 \mathrm{G})$ to third generation $(3 \mathrm{G})$, fourth generation $(4 \mathrm{G})$ and more recently fifth generation (5G) in the developed countries (Porter, 2012).

\subsubsection{Airtel Networks LTD, Uganda}

Uganda major telecommunication companies offering broadband, internet services, fixed and mobile telecoms include MTN Uganda, Airtel Networks LTD, Uganda, Africell Uganda (formerly Orange), Uganda Telecom, Vodafone Uganda, Smile Telecom, Sure Telecom and Smart Telecom. With the rise of internet use and need for better data services especially after the introduction of the fiber optic cable in 2009, Airtel Networks LTD, Uganda has come up with affordable data packages plan to suite its customers based on their needs. 
Mobile financial services and access to other financial institutions like banks is a competitive sector that Airtel Networks LTD, Uganda has envisioned to offer Airtel money services to its best. One network service is a brand service within Airtel Operating Companies in Africa which allows customers to call to their home country while roaming at no extra roaming charges, no incoming call charges, unified customer care services and recharging using home or visited country's recharge voucher. Other services that are completive to other telecoms companies that Airtel Networks LTD, Uganda is gearing up include hello tunes, smartphone network, roaming services, call forwarding and airtime transfer (Africa.airtel.com, 2017).

\subsection{Statement of the Problem}

Most projects within telecommunication industry get executed in an adhoc way without any documentation, guidelines or standard procedure. This lack of proper formal plans brings another new problem of communication breakdown. Stakeholders to these projects lack a better communication link when it comes to understanding the needs and reason behind changes requested (Senior \& Swailes, 2010).

Lack of feedback in change effectiveness and acceptance to the organizational members and more so the affected stakeholders to the changes implemented is another key failure in these projects (Madden \& Savage, 2009). Managers fail to reinforce these changes to the master project plan for purposes of references on the changes that have been implemented within the project or as a resource for training (Dibella, 2013).

When it comes to change execution, project managers fail to align the change process to project management change management process. Change management plans are not well structured in terms of resources, activities, responsibilities and the schedules. Projects mangers also fail to perform a change control which involves making sure that the changes being implemented are kept to the proposed plan without deviating the scope of the projects may it be time, budget, cost or human resources needs.

\subsection{Research Question}

What are the impacts of change preparedness in project success within the telecommunication industry in Uganda?

\section{Theoretical Literature Review}

\subsection{Change Preparedness}

Organizational readiness for change can be perceived to be psychological, structurally, emphasis of financial requirement, readiness for personnel, and informational resources Khammarnia, Ravangard and Asadi (2014), suggest that organizational preparedness for change is multileveled in the sense that it can be at individual level, group or departmental level or even the entire organizational level based on the proposed changes. Kotter (2012) observes that most resistance to changes are attributed to stakeholders not having a better understanding of the changes, individuals feeling that they must learn new skills, some individuals feel that they will lose their status quo and devaluation of their knowledge or skills. 
Several strategies have been suggested by change management experts with much emphasis on organizational readiness for change as opposed to individual change. Organizational readiness for change can be multi-faced since it involves a shared resolve to implement change best referred to as change commitment and the capability to do the change referred to as change efficacy Rafferty, Jimmieson and Armenakis (2012). If organizational readiness for change is high, people are more willing to initiate the changes, put more effort and have less resistant to the changes resulting into a more effective implementation. Pasmore (2012) found out that people become committed to organization changes if they value the changes and need the changes, they have little or no choice or because they are obliged to accept them, they have high levels of commitment to change if the change is in line with what organizational members wanted and when they feel confident to do so.

Armenakis and Bernerth (2007) showed that Lewin's model concept of unfreezing to be like readiness. Readiness for change is described as an individual's attitude, intension and belief pertaining to the extent to which desired changes are required and the organizations capacity to undertake the changes successfully. Like Armenakis and Bernerth (2007), Kotter (1995) argues through his eight-step model that the very start step in change is to build a sense of urgency and need which can be equated to change readiness.

Change management team or project managers use assessment tools to assess the organizational readiness for change in several areas which include organizational assessment, employee assessment, culture and history assessment, sponsor assessment and overall change assessment (Lyons, Swindler \& Offiner, 2009). These tools provide the project managers with early insights into the expected challenges and opportunities they are likely to face during the change process. Based on the outcome of the change assessment, an agreeable strategy that is optimal for the change management effort to align with the size and type of change is adopted finally (Susanto, 2008).

Lorsch (2010) in contingency model found that both the managers and the change agents will vary in the strategies they use in change management process based on the environmental conditions they are enacting the changes. Organizational readiness is a psychological state which should be embraced by all organizational members for them to feel committed to change implementation. Organizations need to come up with the strategies that are aligned with the organization environment for a successful change management process. Organizations strategies may differ in terms of their processes, structure and the key values with which they take priority on. Most projects within telecommunication industry must undergo a series of change assessment before the changes can be done on the production system environment as the cost of implementing these changes is usually high, hence must show readiness to change effectively.

Walker, Armenakis and Bernerth (2007) carried out a research on readiness for change and change resistance about mobile extension that exist between personnel of valley Governorate and identified readiness as the initial realization to change that can be achieved at the initial stages of change process in most cases. Walker, Armenakis and Bernerth (2007) noted that change resistance is very high at this stage because of poor individual attitude preparedness 
for change. Walker, Armenakis and Bernerth (2007) suggestions were that there is need for a more humanistic change management approach which involves behaviors and performance measures that will assist in measuring the readiness for change, thereby reducing resistance to change.

According to Susanto (2008) in his transition model, change readiness involves a stage of ending old ways of doing things in an organization and a transitional preparedness for new beginning. Harris and Armenakis (2007) come up with a model consolidating the theories of change management and made an analysis like Lewin's model in three stages which involved readiness, adoption and institutionalization. Harris, Armenakis and Holt (2007) summarized their findings of change readiness as the state at which employee's reception to change becomes forthcoming by changing the organizational environment, organizational structures and employees' attitudes to the change. Walker, Armenakis and Bernerth (2007) suggested readiness as the point at which employees begin to focus on the past and in anticipation for the changes proposed to take place, resulting into resistant to change. Weber and Weber (2001) in a research on Changes in employee perceptions during organizational change suggested that change readiness as the stage at which employee's interpretation regarding an organization indicate readiness for change. Weber and Weber (2001) concluded that the interpretation of change content and subjective assessment of change, change process, individual attributes and the reaction to change are vital aspects of how an organization is ready to implement changes.

\section{Research Methodology}

\subsection{Research Design}

This study used descriptive research design to answer the question concerning the status quo of the subject in study, since it is more analytical, useful for collecting large amount of data for detailed analysis and easy to quantitatively analyze the data obtained to determine the relationship that exists between dependent and independent variables.

\subsection{Target Population}

The target population for this study was the technical staff within IT department, change management team involved in implementing and configuring changes and the management team involved in approving or rejecting changes in Airtel Networks LTD Uganda. Several strata were created to this population which included core networks team, value add service team, service recovery team, support team, top-level management, middle-level management, lower-level management teams and change management team.

\subsection{Data Collection Method}

Data was collected using online questionnaires with both open and closed ended questions based on the research objectives. Online questionnaires were appropriate to the target population since majority of the respondents were bound to be unavailable in office to fill in hardcopy versions of the questionnaires, and it also allows for partially entry for late completion. 


\section{Macrothink}

\subsection{Data Analysis}

Descriptive statistic was used to transform data into measures of central tendencies for instance mean and measures of dispersion for instance variance, range and standard deviation and measures of relative frequency which included distribution charts like bar graph, charts and frequency distribution tables. Quantitative data from questionnaires was analyzed using Statistical Package for Social Sciences (SPSS) software and Microsoft office presentation suite for instance excel.

\section{Results and Discussion}

The objective of the study was to investigate the role of integrated change control in project success within the telecommunication industry in Uganda and was discussed under the following sub-headings;

\subsection{Impact Analysis}

The respondents were asked if it is of their opinion that impact analysis is conducted at Airtel Networks LTD Uganda when it comes to preparation process for changes requested. Below were the results

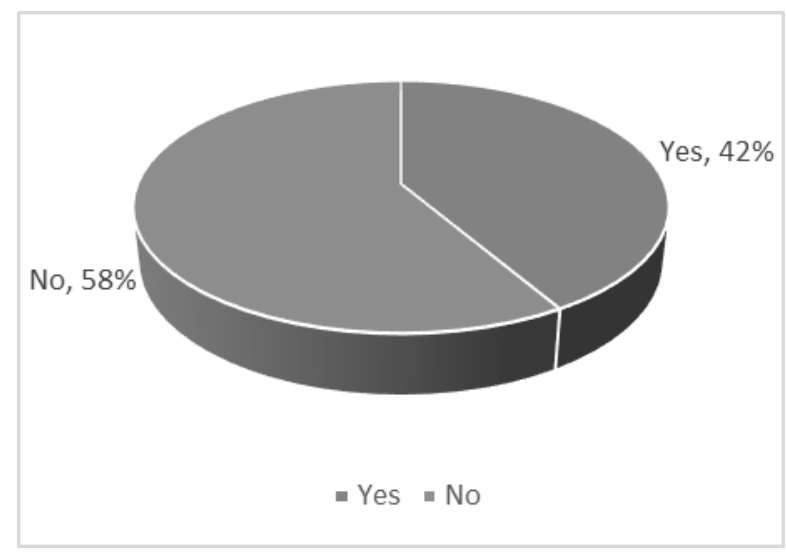

Figure 1. Impact Analysis

Results from Figure 1 show that some unsatisfactorily efforts are done to study impact of the changes requested before they get executed. $58 \%$ of the respondents said that there is no impact analysis made towards the changes requested, with $42 \%$ of the respondents believing that impact analysis is conducted to study the impact of the changes requested before they get executed.

\subsection{Extant Stakeholders are Involved in Change Process}

This study sought to establish the extent to which relevant stakeholders are involved in the change process. The results are presented below. 


\section{Macrothink}

Table 1. Extant Stakeholders are involved in change Process-Move to the next page

\begin{tabular}{|l|l|l|}
\hline Extant & Frequency & Percentage \\
\hline No Extent & 0 & $0 \%$ \\
\hline Low Extent & 11 & $8 \%$ \\
\hline Moderate Extent & 112 & $79 \%$ \\
\hline High Extent & 15 & $8 \%$ \\
\hline Very High Extent & 8 & $6 \%$ \\
\hline Total & $\mathbf{1 4 6}$ & $\mathbf{1 0 0 \%}$ \\
\hline
\end{tabular}

The results of Table 1 show that majority of the respondents with a score of $79 \%$ have a moderate feeling that all relevant stakeholders are usually involved in the change management process. No respondent felt that there is no extent these stakeholders are involved in the change process. The implication here is that majority of the stakeholders to a change process are involved in the change process, whether fully or partially. However, only $8 \%$ of the respondent believe there is a very high extent that all relevant stakeholders are usually involved in the change management process. Kotter (2012) observes that most resistance to changes are attributed to stakeholders not having a better understanding of the changes, individuals feeling that they must learn new skills, some individuals feel that they will lose their status quo and devaluation of their knowledge or skills.

\subsection{Extant to which Organization is Ready for Change}

The respondents were asked to indicate the extent to which they think Airtel Networks LTD Uganda as an organization is ready for change. The findings are presented in the figure below.

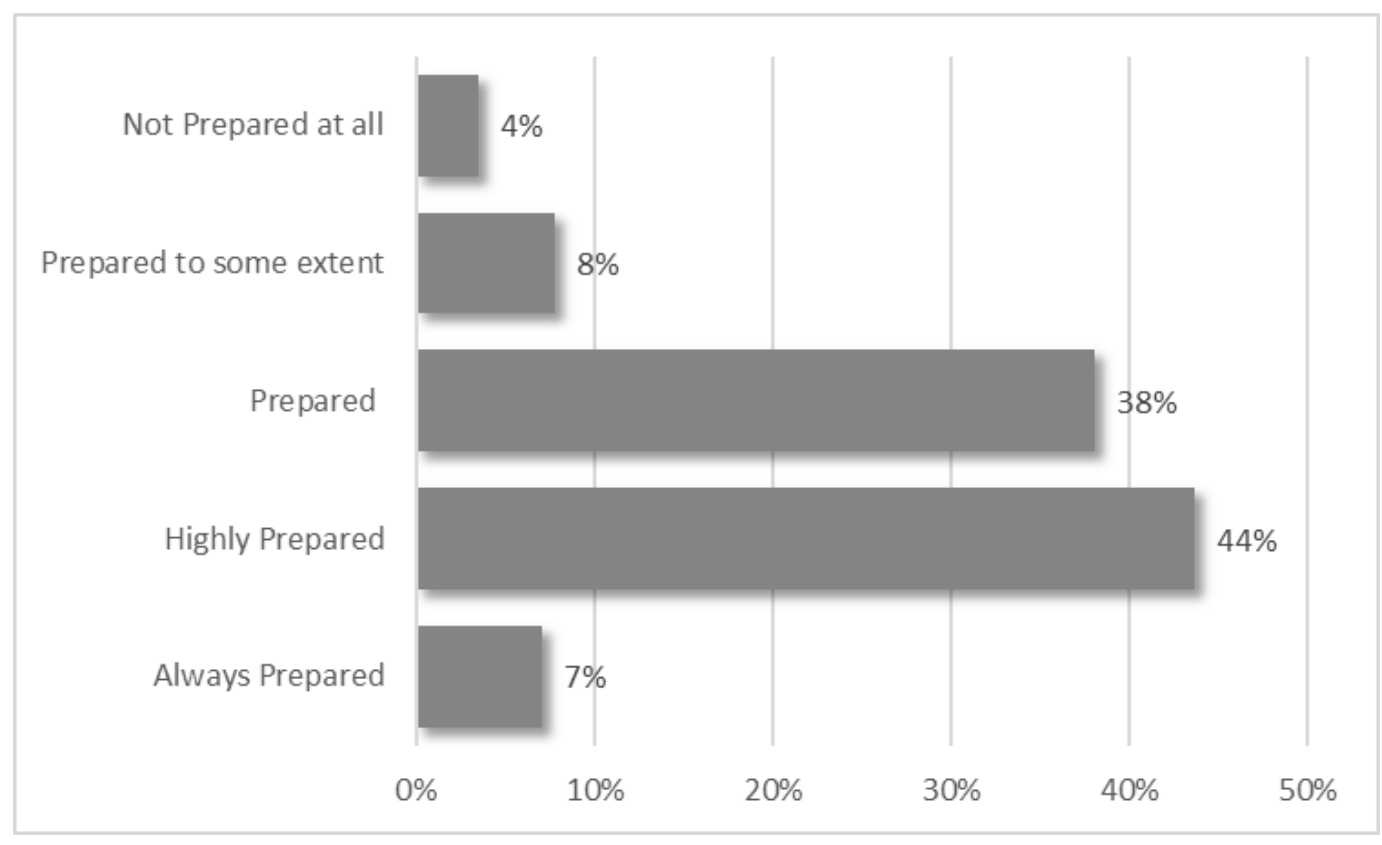

Figure 2. Extant to which Organization is Ready for Change

The results from Figure 2 show that Airtel Networks LTD Uganda is usually ready for change 
with $44 \%$ of the respondent responding that the organization is highly prepared and $38 \%$ of them feeling that the organization is prepared. Only $4 \%$ of the respondents feel that the organization is never prepared at all, implying that a total of $92 \%$ feel that the organization is prepared to some or great extent. Khammarnia, Ravangard and Asadi (2014), suggest that organizational preparedness for change is multileveled in the sense that it can be at individual level, group or departmental level or even the entire organizational level based on the proposed changes.

\subsection{Extant to which Users are Ready for Change}

The respondents were asked to indicate the extent to which they think users of Airtel Networks LTD Uganda are ready for change. The findings are presented in figure below.

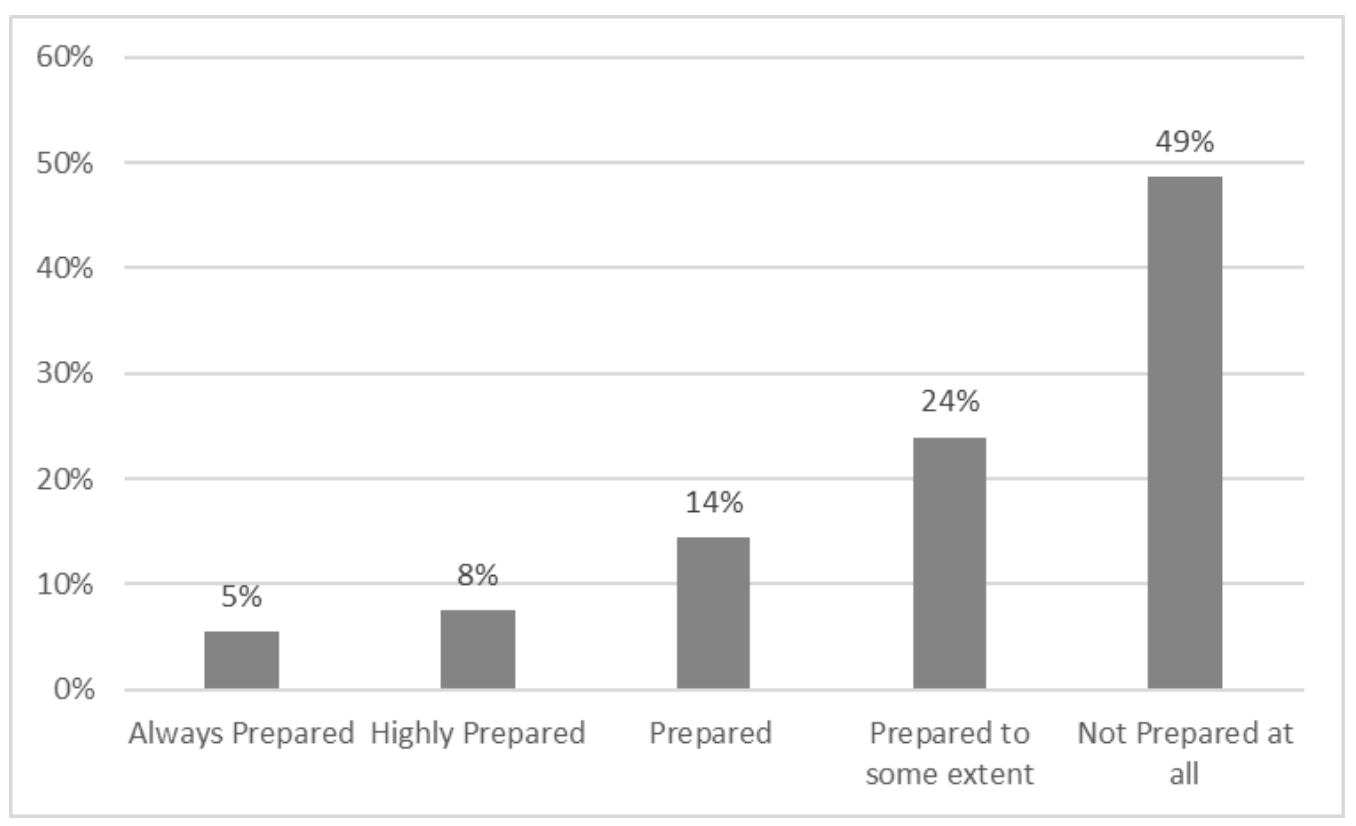

Figure 3. Extant to which Users are Ready for Change

The results from Figure 3 show that $49 \%$ of the respondents feel that users are not prepared at all for changes. Only 5\% of the respondent state that users are always prepared for the changes. This implies that there is a lot of change resistance from users when it comes to implementing new changes to the organization. However, comparing organization readiness versus user readiness for change, A total of $92 \%$ of the respondents feel that organization is prepared for change as opposed to $51 \%$ of the respondents that feel users are ready for change. Weber and Weber (2001) concluded that the interpretation of change content and subjective assessment of change, change process, individual attributes and the reaction to change are vital aspects of how an organization is ready to implement changes.

\subsection{Extant to which Change Proposals are Communicated to the Team}

The respondents were asked to indicate the extent to which change proposed are communicated to the team. The findings were presented as below. 


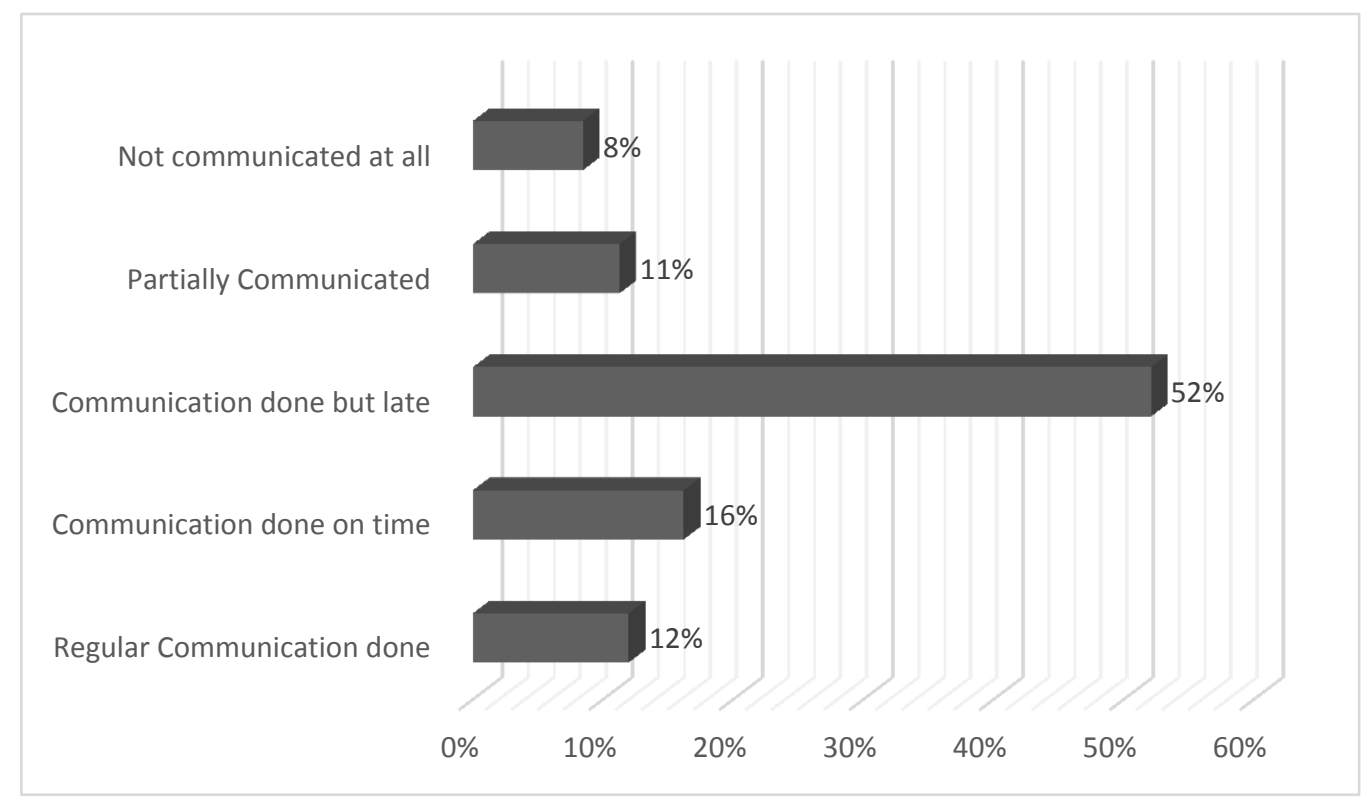

Figure 4. Extant to which Change Proposals are Communicated to the team

The finding as illustrated in Figure 4 show that $52 \%$ of respondents indicate that communication is done but late about change proposals. $12 \%$ of the respondents indicate that regular communication is done and only $8 \%$ of the respondents indicated that no communication is done to the team at all. This however translates to $92 \%$ of respondent showing that there is some communication done to the team, with discrepancies in the rate of communication. According to Fullan (2005), communication that spans across both horizontal and vertical structures and two way brings with it more knowledge about the status of the changes. Cohen, Manion and Morrison (2000) emphasizes that individuals need more communication about the changes and about how these changes will affect them personally and in their working environment.

\subsection{Change Preparedness Concerns}

The study sought to establish the extent to which various change preparedness concerns aspects affect integrated change control process in Airtel Networks LTD Uganda. A scale of 1-5 was used to interpret the results of the study.

Mean $(\overline{\mathbf{x}})$ was computed using the formulae below.

Mean $(\overline{\mathbf{x}})=[($ Number of Respondents to response 1$) *($ weighting of response 1$)+($ Number of Respondents response 2) *(weighting of response 2) $+\ldots$ (Number of Respondents $n$ ) $*$ (weighting of response $\mathrm{n}$ )] / (Total number of respondents)

The scores "Strongly Disagree" and "Disagree" were represented by mean score, equivalent to 0 to 2.4 on the continuous Likert scale $(0 \leq$ Disagree $\leq 2.4)$. The scores of 'Not Sure' were equivalent to 2.5 to 3.4 on the Likert scale $(2.5 \leq$ Not Sure $\leq 3.4)$. The score of "Agree" and "Strongly Agree" represented were equivalent to 3.5 to 5.0 on the Likert scale $(3.5 \leq$ Agree $\leq$ $5)$. 
Table 2. Extant to which Change Proposals are Communicated to the Team

\begin{tabular}{|l|l|l|}
\hline Change Preparedness Concerns & Mean $(\overline{\mathbf{x}})$ & Standard Deviation \\
\hline $\begin{array}{l}\text { Lack of proper communication of changes proposed } \\
\text { to the team has always led to change execution failures. }\end{array}$ & 4.56 & 1.63 \\
\hline $\begin{array}{l}\text { Failure to involve all stateholders in the change } \\
\text { process has always led to change process failure. }\end{array}$ & 4.48 & 1.45 \\
\hline $\begin{array}{l}\text { Change resistance is high due to lack of } \\
\text { proper change preparedness. }\end{array}$ & 4.67 & 1.72 \\
\hline $\begin{array}{l}\text { Users are less motivated to the change process } \\
\text { if the change assessment process is overlooked }\end{array}$ & 3.80 & 0.84 \\
\hline
\end{tabular}

The study result from Table 2 show that respondents agree with the statement that lack of proper communication of changes proposed to the team has always led to change execution failures with a mean score of 4.56 from the Likert scale. A mean of 4.48 of the respondents agree that change process failures are attributed by failure to involve all the stakeholders. The respondents also agree that change resistance is high due to lack of proper change preparedness with a mean score of 4.67. However, the respondents were not sure if users are less motivated to the change process if the change assessment process is overlooked with a mean score of 3.80. Cameron and Green (2012) based their research on over 1000 managers in a research on large scale planned change process to an organization found out that change process is successful when communication on change necessity and regularly updates on the change process by managers is enhanced. Kotter (2012) observes that most resistance to changes are attributed to stakeholders not having a better understanding of the changes, individuals feeling that they must learn new skills, some individuals feel that they will lose their status quo and devaluation of their knowledge or skills.

\subsection{Tools Used for Assessing Organizational change}

The respondents were asked to identify the tools used for assessing organizational change at Airtel Networks LTD Uganda, and the results were as below. 


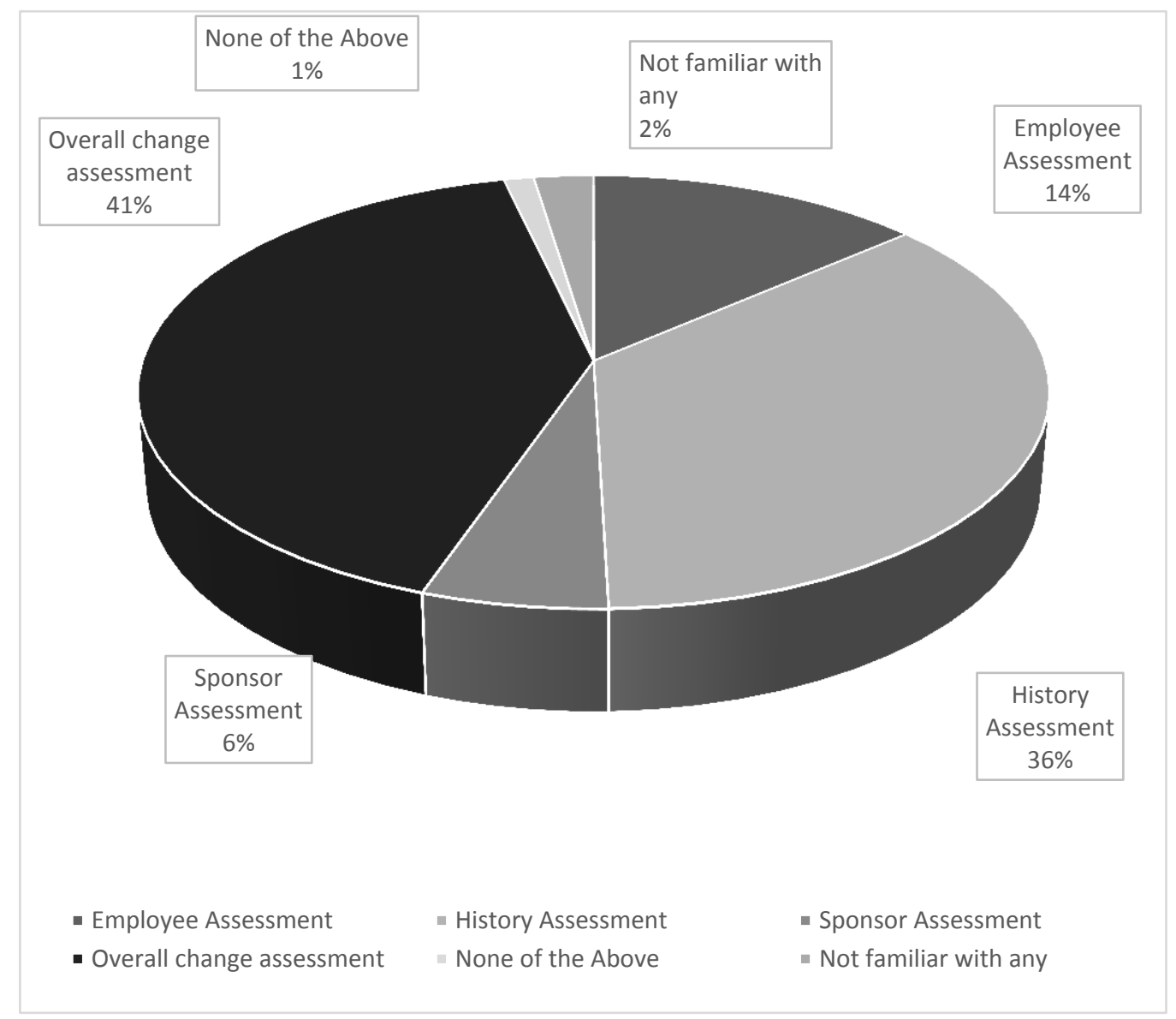

Figure 5. Tools Used for Assessing Organizational Change

The results of Figure 5 show that a great number of respondents believe that the organization uses overall change assessment to ascertain changes that have been executed with a $41 \%$ lead. $36 \%$ of the respondent strongly believe that the organization uses history assessment which involves use of results and outcomes of past change implementation. It is worth noting that $1 \%$ of the respondent did not identify any of the listed responses and $2 \%$ of the respondents were not familiar with the assessment methods asked. $14 \%$ of the respondents believe that employee assessment which involves studying employee attitudes and willingness to participate in a change process is used while $6 \%$ of the respondents believe that sponsor assessment is used. These tools provide the project managers with early insights into the expected challenges and opportunities they are likely to face during the change process. Based on the outcome of the change assessment, an agreeable strategy that is optimal for the change management effort to align with the size and type of change is adopted finally (Susanto, 2008).

\subsection{Areas Where Organization Fails in Change Preparedness}

This study sought to establish all possible areas where organization fails in change preparedness in the areas highlighted below. More than one selection was acceptable. 
Table 3. Areas where organization fails in change preparedness

\begin{tabular}{|l|l|l|}
\hline Change Preparedness Areas & Respondents & Percentage \\
\hline Identifying the reason for change & 122 & $36.09 \%$ \\
\hline Impact analysis & 71 & $21.01 \%$ \\
\hline Communication & 104 & $30.77 \%$ \\
\hline Change reviews & 41 & $12.13 \%$ \\
\hline None of the above & 0 & $0 \%$ \\
\hline
\end{tabular}

Results from Table 3 indicate that $36 \%$ of respondents believe that the organization fails to identify the reason for change in the initial stages of change process. $30.77 \%$ of the respondents think that communication breakdown lacks during change preparedness. Only $12 \%$ of the respondents think that change reviews of the proposed changes during change process are the weakest link in the organization while $21 \%$ think that the organization fails to perform the correct and optimal impact analysis of the changes proposed. According to Gorse et al., (2003), persuasive communication can be a way to articulate reasons for change, recognition for difficulties and standards for how change will occur to shape individuals view of change efforts. Communication has a great effect on creating an environment for readiness for change while creating trust and commitments to the organization (Frahm \& Brown, 2007).

\section{Recommendations}

The study recommends that Airtel Networks LTD Uganda continuously engages in the Change management process to exploit fully its internal resources in the strategy implementation process while remaining relevant not only to its own operations but also to the ever-changing environmental dynamics in the telecommunication industry. Some of the inadequacies in the application of change management relate to relevant skill on project management which will enable them to understand clearly the strategy and to communicate to management what changes are necessary to improve the change management process. To this end, it is suggested that staff should be trained more often to be able to participate effectively in strategy implementation.

\section{Areas for Further Research}

The approach under investigation was to gather the technical competencies related to change management and did not look closely at details of how individual behavioral competencies affect the project outcome. The area of behavioral competencies and assessment of the organizational context and the extent and nature of change management activities that will be required to ensure success would be a relevant research topic of its own and an interesting expansion to this topic. Further research can be conducted on the effects of change management and its implications to project failure.

\section{Conclusion}

The study concludes that communication on changes at Airtel Networks LTD Uganda is low and when done, it is done late. Communication plans begin with a careful analysis of the audiences, key messages and the timing for those messages. It is evident that initial 
communication when changes are being planned is not done to all the relevant stakeholders for them to undertake necessary planning actions. The change management team or project leaders must design a communication plan that addresses the needs of frontline employees, supervisors and executives with each audience having a need for information based on their role in the implementation of the change. The results of the study further show that most employees are never ready for changes. Airtel Networks LTD Uganda as an organization is prepared to some extent though not as much as it would be expected of it. Change readiness assessments can include organizational assessments, culture and history assessments, employee assessments, sponsor assessments and change assessments, most of which are lacking at Airtel Networks LTD, Uganda. Training is the cornerstone for building knowledge about the change and the required skills to succeed in the future state. The study shows that trainings and training materials availability after an execution of the change are never or not always availed to the teams at Airtel Networks LTD Uganda. Feedback elicitation from all relevant stakeholders' lack at Airtel Networks LTD Uganda on the changes that have been implemented. It would be beneficial for Change managers to analyze feedback and implement corrective action based on this feedback to ensure full adoption of the changes. Finally, it was observed that Airtel Networks LTD Uganda doesn't have a unified change management process that incorporates an integrated change control section comprised of Change board that sits down to review, analyze, approve, reject or return change requests raised by different stakeholders of the organization at any point in time.

\section{Acknowledgements}

The authors would like to express gratitude to the entire management and staff of Airtel Networks LTD, Uganda for their cooperation in participating in the research process.

\section{References}

Armenakis, A. A., \& Harris, S. G. (2007). Reflections: our journey in organizational change research and practice, Journal of Change Management, 9(2), 127-142.

https://doi.org/10.1080/14697010902879079

Armenakis, A. A., \& Harris, S. G. (2012). Crafting a change message to create transformational readiness, Journal of Organizational Change Management, 15(2), 169-183. https://doi.org/10.1108/09534810210423080

Armenakis, A. A., \& Bedeian, A. G. (2007). Organizational change: a review of theory and research in the 1990s, Journal of Management, 25(3), 293-315.

https://doi.org/10.1177/014920639902500303

Armenakis, A. A., Harris, S. G., \& Field, H. S. (2007). Making change permanent: A model for institutionalizing change interventions, In W. Passmore \& R. Woodman (Eds.), Research in Organizational Change and Development, 12, 289-319. JAI Press, Greenwich, CT.

Armenakis, A. A., Harris, S. G., \& Mossholder, K. W. (2007). Creating readiness for organizational change, Human Relations, 46(6), 681-703.

https://doi.org/10.1177/001872679304600601 
Bharti, A. (2015). About Bharti Airtel. [Online] Available: http://africa.airtel.com.

Cameron, E., \& Green, M. (2012). Making sense of change management: A complete guide to the model, tools and techniques of organizational change. (3rd ed.). London: Kogan Page Limited.

Cohen, L., Manion, L., \& Morrison, K. (2000) Research Methods in Education. (5 ${ }^{\text {th }}$ ed.) Routledge Falmer, London.

Dibella, A. (2013). Critical perceptions of organizational change. Journal of Change Management, 7(3), 231-232.

Fullan, M. (2005). Leadership \& sustainability: Systems thinkers in action. Thousand Oaks, CA: Corwin Press.

Gorse, C. A., \& Emmitt, S. (2003). Investigating interpersonal communication during construction progress meetings: challenges and opportunities. Engineering, Construction and Architectural Management, 10(4), 234-244. https://doi.org/10.1108/09699980310489942

Ken, W. (2017). Asia's high Telecom growth threatened. Telecommunications, Telecom Magazine, Horizon House.

Khammarnia, M., Ravangard, R., \& Asadi, H. (2014). The relationship of attitudinal empowerment and readiness for organizational changes in health workers, Lorestan, Iran, The Journal of the Pakistan Medical Association, 64(5), 537-541.

Kotter, J. P. (1995). Leading change: Why transformation efforts fail, Harvard Business Review, 73(2), 59- 67.

Kotter, J. P. (1996). Leading Change, Harvard Business School Press, Boston, Massachusetts.

Lorsch, J. W. (2010). A Contingency Theory of Leadership. Handbook of Leadership Theory and Practice, edited by Nitin Nohria and Rakesh Khurana. Harvard Business Press, Chap. 15

Lyons, J., Swindler, S., \& Offiner, A. (2009). The impact of leadership on change readiness in the US military, Journal of Change Management, 9(4) 459-475.

https://doi.org/10.1080/14697010903360665

Madden, G., \& Savage, S. J. (2009). Telecommunications and economic growth, International Journal of Social Economics, 27, 893-906.

https://doi.org/10.1108/03068290010336397

Michael, P. E. (2012). Competitive Strategy: Techniques for Analyzing Industries and Competitors. The Free Press, First Free Press Edition.

Pasmore, W. A. (2012). Research in organizational change and development. Bingley, UK: Emerald Group Publishing Limited.

Project Management Institute (2013). A guide to the Project Management body of Knowledge (5th ed.). Newtown Square, Pennsylvania: Project Management Institute, Inc. Publications. 
Senior, B., \& Swailes, S. (2010). Organizational Change. Pearson Education, Harlow.

Susanto, A. B. (2008). Organizational readiness for change: a case study on change readiness in a manufacturing company in Indonesia. International Journal of Management Perspectives, 2(1), 50-61.

Weber, P. S., \& Weber, J. E. (2001). Changes in employee perceptions during organizational change, Leadership \& Organization Development Journal, 22(5), 291.

https://doi.org/10.1108/01437730110403222

\section{Copyright Disclaimer}

Copyright for this article is retained by the author(s), with first publication rights granted to the journal.

This is an open-access article distributed under the terms and conditions of the Creative Commons Attribution license (http://creativecommons.org/licenses/by/3.0/). 